\title{
Penerapan Finite State Automata Pada Vending Machine Susu Kambing Etawa
}

\author{
Kartika Handayani, Dinar Ismunandar, Sukmawati Anggraini Putri, Windu Gata
}

\begin{abstract}
Etawa crossbreed goat milk is highly nutritious milk which has many benefits for the human body. The distribution of etawa goat milk products is currently only limited to sales in a vehicle or market place so that the benefits have not been evenly felt by the community. Therefore, a Vending Machine (VM) is designed for selling etawa goat milk for the distribution of etawa goat milk products using flavor variants using Finite State Automata (FSA) type of Non-Deterministic Finite Automata (NFA). The FSA is used to illustrate the etawa's logic logic for Etawa goat milk. FSA is an abstract machine in the form of a mathematical model system with discrete input and output consisting of strings and labels with output consisting of Os and 1 s that can recognize the simplest language (regular language) that captures patterns in data and can be implemented in a real way so that it can be understood by logic human. In VM etawa goat milk using the FSA comes with two payment methods namely using cash and using $e$ money. The design of etawa goat milk VM using FSA is expected to be developed so that the benefits of etawa goat milk products can be enjoyed by the wider community, especially urban communities.
\end{abstract}

Index Terms - Finite State Automata; Goat Milk; Language and Automata; Vending Machine.

Abstrak--Susu kambing peranakan etawa merupakan susu bergizi tinggi yang memiliki banyak manfaat untuk tubuh manusia. Persebaran produk susu kambing etawa saat ini hanya sebatas penjualan di kendai atau market place sehingga manfaatnya belum merata dirasakan oleh masyarakat.Oleh karena itu, dirancang Vending Machine (VM) untuk penjualan susu kambing etawa untuk persebaran produk susu kambing etawa varian rasa menggunakan Finite State Automata (FSA) jenis NonDeterministic Finite Automata (NFA). FSA digunakan untuk menggambarkan alur logika VM susu kambing etawa ini. FSA merupakan mesin abstrak berupa sistem model matematika dengan masukan dan keluaran diskrit terdiri dari string dan label dengan output terdiri dari 0s

Kartika Handayani, Ilmu Komputer, STMIK Nusa Mandiri, Jakarta, Indonesia, email: 14002416@nusamandiri.ac.id

Dinar Ismunandar, Ilmu Komputer, STMIK Nusa Mandiri, Jakarta, Indonesia, email: 14002421@nusamandiri.ac.id

Sukmawati Anggraeni Putri, IImu Komputer, STMIK Nusa Mandiri, Jakarta, Indonesia, email: sukmawati@nusamandiri.ac.id

Windu Gata, IImu Komputer, STMIK Nusa Mandiri, Jakarta, Indonesia, email windu@nusamandiri.ac.id dan 1s yang dapat mengenali bahasa paling sederhana (bahasa reguler) yang menangkap pola dalam data dan dapat diimplementasikan secara nyata sehingga dapat dipahami oleh logika manusia. Dalam VM susu kambing etawa menggunakan FSA dilengkapi dengan dua metode pembayaran yaitu menggunakan uang tunai dan menggunakan e-money. Perancangan VM susu kambing etawa menggunakan FSA diharapkan dapat dikembangkan sehingga manfaat dari produk susu kambing etawa dapat dinikmati oleh masyarakat luas, khususnya masyarakat perkotaan.

Kata Kunci- Bahasa dan Automata; Finite State Automata; Susu Kambing; Vending Machine;

\section{PENDAHULUAN}

$\mathrm{K}$ ambing etawa atau di Indonesia lebih dikenal sebagai kambing Peranakan Etawa (PE) memiliki tempat tersendiri dikalangan peternak. Perkembangan dan minat dari peternak dalam membudidayakan kambing etawa meningkat pesat dari tahun ke tahun. Salah satu produk yang dihasilkan kambing etawa adalah susu [1]. Susu adalah cairan berwarna putih bernilai gizi tinggi yang dihasilkan oleh kelenjar susu mamalia. Secara kimiawi susu mempunyai susunan sebagai berikut: air $(87,20 \%)$, lemak $(3,70 \%)$, protein $(3,50 \%)$, laktosa $(4,90 \%)$, dan mineral $(0,07 \%)$. Susu kambing memiliki kandungan gizi dan kandungan vitamin B1 yang lebih unggul dari susu sapi dan memiliki lemak dan protein yang mudah dicerna tubuh sehingga menekan timbulnya reaksi alergi.[2] Hasil penelitian Sunarlim dkk (1992) menunjukkan bahwa susu kambing mempunyai kandungan protein $4,3 \%$ dan kandungan lemak $2,8 \%$, nilai ini relatif lebih baik dibandingkan kandungan susu sapi yang mempunyai kandungan protein $3,8 \%$ dan kandungan lemak sebessar $5,0 \%$ [3][4].

Manfaat yang bisa diperoleh dari susu kambing antara lain adalah membantu proses penyembuhan berbagai macam penyakit maupun perawatan tubuh serta menjaga stamina, susu kambing juga dapat membantu meningkatkan kemampuan reproduksi, menjaga tumbuh kembang janin, membantu proses persalinan normal, meningkatkan kualitas ASI, membantu organ pencernaan balita, meningkatkan berat badan serta daya tahan tubuh balita agar tahan terhadap perubahan cuaca maupun makanan yang mengandung 
pengawet, yang dapat memicu alergi pada balita.[5] Dengan berbagai manfaat yang diperoleh dari susu kambing, saat ini susu kambing telah banyak dipasarkan dengan inovasi varian rasa melalui gerai toko, media sosial maupun dengan menggukanan $e$ commerce.

Salah satu strategi pemasaran yang bisa digunakan untuk memasarkan susu kambing etawa adalah dengan menggunakan vending machine (VM). VM adalah sebuah mesin yang beroperasi secara standalone yang dapat melayani transaksi pembelian berbagai kebutuhan manusia. VM biasanya berbentuk kotak besi yang pada bagian depannya dilapisi kata agar produk dapat dilihat oleh pembeli[6][7]. Perkembangan VM di Indonesia masih sangat muda. Berdasarkan data Kompas (2019) baru ada 4.000 Vending Machine untuk melayani 250juta penduduk Indonesia. Persebaran VM di Indonesia untuk saat ini, masih terpusat pada daerah perkotaan saja[6]. Sehingga, vending machine penjualan susu kambing etawa ini dapat dirancang untuk memasarkan produk susu kambing etawa sehingga manfaatnya dapat dinikmati oleh masyarakat luas khususnya masyarakat perkotaan.

Finite State Automata (FSA) digunakan untuk menggambarkan alur logika VM susu kambing etawa ini. FSA merupakan mesin abstrak berupa sistem model matematika dengan masukan dan keluaran diskrit terdiri dari string dan label dengan output terdiri dari 0s dan 1s yang dapat mengenali bahasa paling sederhana (bahasa reguler) yang menangkap pola dalam data dan dapat diimplementasikan secara nyata sehingga dapat dipahami oleh logika manusia [8][9][10]. FSA adalah model matematika yang dapat menerima input dan mengeluarkan output yang memiliki state yang berhingga banyaknya dan dapat berpindah dari satu dari jenisnya yaitu FSA terdapat mesin bahasa yang dapat mengenali, menerima dan menolak yang terdapat pada mesin FSA jenis Deterministic Finite Automata (DFA) dan Non-deterministic Finite Automata (NFA) [11].

Finite State Automata (FSA) digunakan untuk menggambarkan alur logika VM susu kambing etawa ini. FSA merupakan mesin abstrak berupa sistem model matematika dengan masukan dan keluaran diskrit terdiri dari string dan label dengan output terdiri dari 0s dan $1 \mathrm{~s}$ yang dapat mengenali bahasa paling sederhana (bahasa reguler) yang menangkap pola dalam data dan dapat diimplementasikan secara nyata sehingga dapat dipahami oleh logika manusia [8][9][10]. FSA adalah model matematika yang dapat menerima input dan mengeluarkan output yang memiliki state yang berhingga banyaknya dan dapat berpindah dari satu dari jenisnya yaitu FSA terdapat mesin bahasa yang dapat mengenali, menerima dan menolak yang terdapat pada mesin FSA jenis Deterministic Finite Automata (DFA) dan Non-deterministic Finite Automata (NFA) [11].
FSA memiliki sifat-sifat seperti pita masukan (input tape) berisi rangkaian simbol (string) yang berasal dari himpunan simbol / alfabet, setiap kali setelah membaca satu karakter, posisi read head akan berada pada simbol berikutnya, setiap saat FSA berada pada status tertentu dan banyaknya status yang berlaku bagi FSA adalah berhingga [12]. Sebagai contoh mesin FSA output bisa dengan menggunakan simulasi VM yang mana konsep dasar dari alat tersebut adalah metode FSA output. Sebuah VM biasanya menjual 1 (satu) jenis barang, seperti : makanan ringan (snack), minuman, pembelian tiket seperti halnya di KRL, dan sebagainya[13][14].

Dalampenelitian sebelumnya VM menggunakan FSA juga digunakan dalam aplikasi simulasi penjualan yoghurt walagri [15], VM menggunakan nondeterministik finite outomata digunakan dalam aplikasi penjualan sereal dua pembayaran [9] , Selain VM, dalam penelitian sebelumnya FSA juga diterapkan dalam Implementasi Sistem Monitoring Polusi Udara Berdasarkan Indeks Standar Pencemaran Udara [16], Penerapan Pergantian Desktop Background [17], Implementasi Aplikasi Alat Bantu Pembelajaran [18], Penerapan Pada Proses Peminjaman Buku di Perpustakaan Universitas Kristen Satya Wacana [19] dan Implementasi FSA pada Aplikasi Pembelajaran Aksara Sunda[20].

Penggunaan VM menggunakan FSA juga dilakukan pada Desain VM Rokok terintegrasi KTP untuk mengurangi perokok aktif yang berusia dibawah umur[21]. FSA tidak hanya digunakan dalam VM, dalam Identifikasi File JPEG dengan Metode Signature-Based Carving FSA digunakan untuk dapat mengidentifikasi dan me-recoveryfile JPEG [22]. Penerapan FSA Pada Simulasi VM Susu Kambing Etawa, belum pernah ada dalam penelitian sebelumnya. Dalam rancangan FSA Simulasi VM Susu Kambing Etawa digunakan dua sistem pembayaran yaitu tunai dan e-money menggunakan kartu. Untuk menggambarkan alur aktivitas VM, digunakan menggunakan Unified Modelling Language (UML) yang terdiri dari usecase diagram dan Activity diagram. UML adalah bahasa yang digunakan untuk menjelaskan kebutuhan, membuat analisa dan desain serta menggabarkan arsitektur [23]. Use case diagram diagram akan menjalaskan interaksi antara penggukan dan sistem yang dirancang, sedangakn activity diagram aliran kerja dari sistem yang dirancang [24]. Penerapan FSA Pada Simulasi VM Susu Kambing Etawa dilakukan untuk merancang VM Susu Kambing Etawa menggunakan FSA sehingga dapat dikembangkan dan bermanfaat dalam pemasaran. 


\section{LANDASAN TEORI}

\section{A. Finite State Automata}

FSA adalah model matematika yang dapat menerima input dan mengeluarkan output yang memiliki state yang berhingga banyaknya dan dapat berpindah dari satu dari jenisnya yaitu FSA terdapat mesin bahasa yang dapat mengenali, menerima dan menolak yang terdapat pada mesin FSA jenis Deterministic Finite Automata (DFA) dan Non-deterministic Finite Automata (NFA) [11]. Secara formal FSA dinyatakan oleh 5 tupel atau $\mathrm{M}=(\mathrm{Q}, \Sigma, \delta, \mathrm{S}, \mathrm{F})$ dimana:

$\mathrm{Q}=$ himpunan state/kedudukan

$\Sigma=$ himpunan simbol input/masukan/abjad

$\delta=$ fungsi transisi

$\mathrm{S}=$ state awal/kedudukan awal (initial state),

$\mathrm{S} \in \mathrm{Q} F=$ himpunan state akhir, $\mathrm{F} \cap \mathrm{Q}$ (jumlah state akhir pada suatu FSA bisa lebih dari satu)

\section{B. Non-deterministic Finite Automata}

Sebuah Nondeterministic Finite Automaton (NFA) merupakan jenis finite state machine (FSM) dimana salah satu nextstate tidak sepenuhnya ditentukan oleh current state ataupun input. Himpunan dari possible next states menyatakan bahwa automata dapat berpindah dari state tertentu (qa) ke state yang lain (qb) sebagai tanggapan terhadap suatu input $(\alpha)$. Dalam NFA, jumlah start state dan transisi untuk setiap anggota himpunan input $(\Sigma)$ tidak harus tepat satu[25].

\section{METODE PENELITIAN}

Metode yang diterapkan dalam Penerapan Konsep Pada Aplikasi Simulasi Susu Kambing FSA VM ini disajikan pada gambar 1. Antara lain 1. Finite State Automata VM Susu Kambing Etawa, 2. Perancangan Sistem VM Susu Kambing Etawa, 3. Desain VM Susu Kambing Etawa.

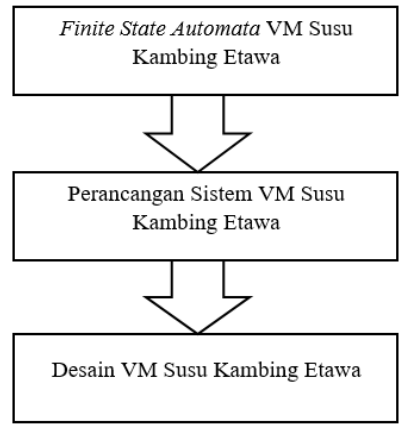

Gambar 1. Metode Penelitian
1. Finite State Automata (FSA) VM Susu Kambing Etawa

Pada tahap ini dilakukan penggambaran FSA menggunakan non-deterministik finite automata.

2. Perancangan Sistem VM Susu Kambing Etawa Pada tahap ini dilakukan perancangan sistem menggunakan (Unified Modelling Language) yang terdiri dari Usecase diagram dan Activity diagram.

3. Desain VM Susu Kambing Etawa

Pada tahap ini dilakukan desain tampilan antarmuka saat VM diimplementasikan

\section{HASIL DAN PEMBAHASAN}

1. Finite state automata (FSA) VM Susu Kambing Etawa

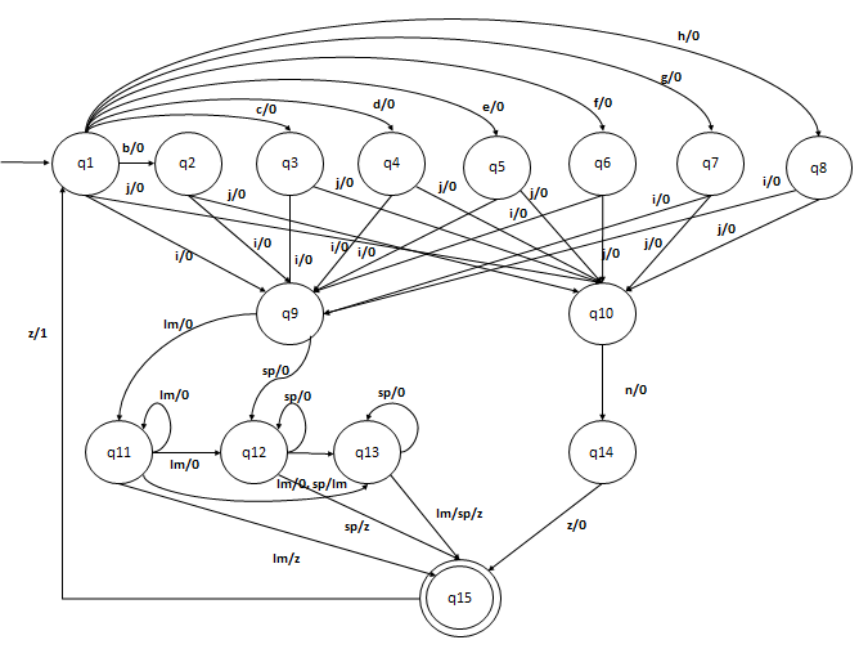

Gambar 2. FSA VM Susu Kambing Etawa

Pada diagram state diatas, konfigurasi mesin dijelaskan sebagai berikut:

$Q=\{q 1, q 2, q 3, q 4, q 5, q 6, q 7, q 8, q 9, q 10, q 11, q 12$, $\mathrm{q} 13, \mathrm{q} 14, \mathrm{q} 15\}$

$\Sigma=\{\mathrm{b}, \mathrm{c}, \mathrm{d}, \mathrm{e}, \mathrm{f}, \mathrm{g}, \mathrm{h}, \mathrm{i}, \mathrm{j}, \mathrm{k}, \mathrm{l}, \mathrm{m}, \mathrm{n}, \mathrm{z}, \mathrm{lm}, \mathrm{sp}\}$

$\mathrm{S}=\{\mathrm{q} 1\}$

$\boldsymbol{\Delta}=\{0,1,1 \mathrm{~m}, \mathrm{sp}\}$

Pada diagram state ini, mesin memiliki beberapa state yang menyimbolkan proses, sebagai berikut.

$\mathrm{q} 1=$ Start State

q2= Susu Kambing Rasa Jahe

q3 = Susu Kambing Rasa Coklat

q4= Susu Kambing Rasa Strawberry

q5= Susu Kambing Rasa Kopi

q6= Susu Kambing Rasa Kurma

q7= Susu Kambing Rasa Green Tea

q8= Susu Kambing Rasa Original

q9= Tipe Pembayaran Tunai

q10= Tipe Pembayaran Cashless

q11= Menerima Input Tunai 5000

q12= Menerima Input Tunai 10000

q13= Total Penambahan State K dan L

q14= Tapping Kartu E-Money Cashless 


\section{q15= Susu Kambing Turun (Final State Diagram)}

Diagram state tersebut menerima masukan berupa state yang akan dituju serta nol dan satu. Nol berarti diagram state tersebut berlanjut ke state berikutnya, sedangkan menerima masukan satu berarti mesin telah menyelesaikan tugasnya (sudah mengeluarkan susu kambing sesuai varian rasa yang dipilih) dan akan kembali ke state awal. Diagram state tersebut juga memiliki beberapa masukan spesial untuk pembayaran tunai, yaitu $\mathrm{lm}$, dan sp, yang menyimbolkan uang tunai 5.000 dan 10.000 rupiah. Sedangkan, untuk state yang dituju, disimbolkan masukannya dengan huruf kecil dari state yang akan dituju. Mesin tersebut akan berjalan apabila masukan yang dituju sesuai dengan state yang akan dituju.

Pada state awal, pengguna akan diminta untuk memilih susu kambing rasa apa yang diinginkan, misalnya pengguna memilih susu kambing rasa original, maka state awal q1, akan menuju ke state q8. Setelah susu dipilih maka akan muncul pilihan metode pembayaran, jika menggunakan uang tunai, maka akan menuju ke state q9, sedangkan jika menggukanan emoney maka akan menuju ke state q10. Jika pengguna memilih e-money maka akan diminta untuk tap kartu emoney menuju state q14 dan setelah itu susu kambing yang telah dipilih akan keluar. Namun, jika pengguna memilih menggunakan uang tunai, maka pengguna akan diminta memasukkan uang. Jika pengguna memilih memasukan uang 5000, maka akan menuju ke state q11, jika pengguna memilih memasukkan uang 10000 maka akan menuju ke state q12. Kemudian kedua state, q11 dan q12 akan di jumlahkan sehingga menuju ke state q13. Setelah itu susu kambing yang telah dipilih akan akan keluar ke q15.

\section{Perancangan Sistem VM Susu Kambing Etawa}

\section{a. Use Case Diagram}

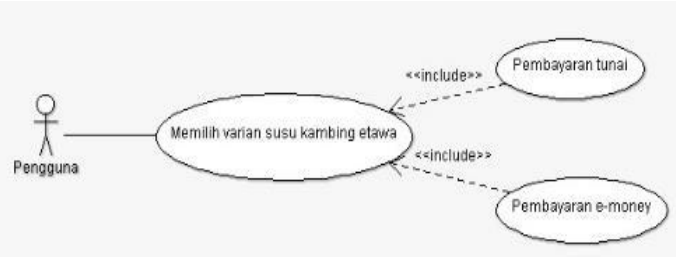

Gambar 3. Use Case Diagram VM Susu Kambing Etawa

Pada gambar 3 menjelaskan use cese diagram dengan aktor pengguna yang dapat melakukan pemilihan varian susu kambing. Setelah proses pemilihan varian susu kambing, barulah pengguna dapat memilih metode pembayaran yaitu pembayaran menggunakan uang tunai atau pembayaran menggunakan $e$-money.

\section{b. Activity Diagram}

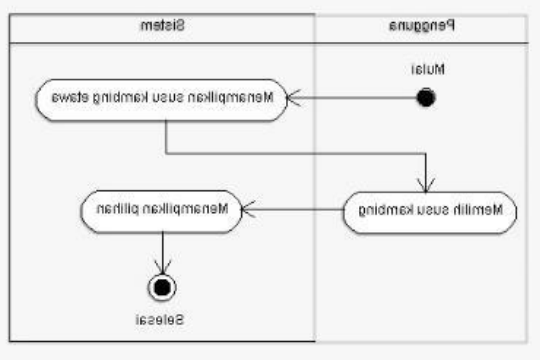

Gambar 4. Activity Diagram Memilih Susu Kambing Etawa

Pada gambar 4 menampilkan activity diagram memilih susu kambing etawa. Saat awal, sistem VM akan menampilkan varian susu kambing dilayar. Kemudian pengguna dapat memilih varian susu kambing yang diinginkan. Setelah proses pemilihan susu kambing dilakukan, sistem VM akan memberi tanda pada susu kambing yang telah dipilih.

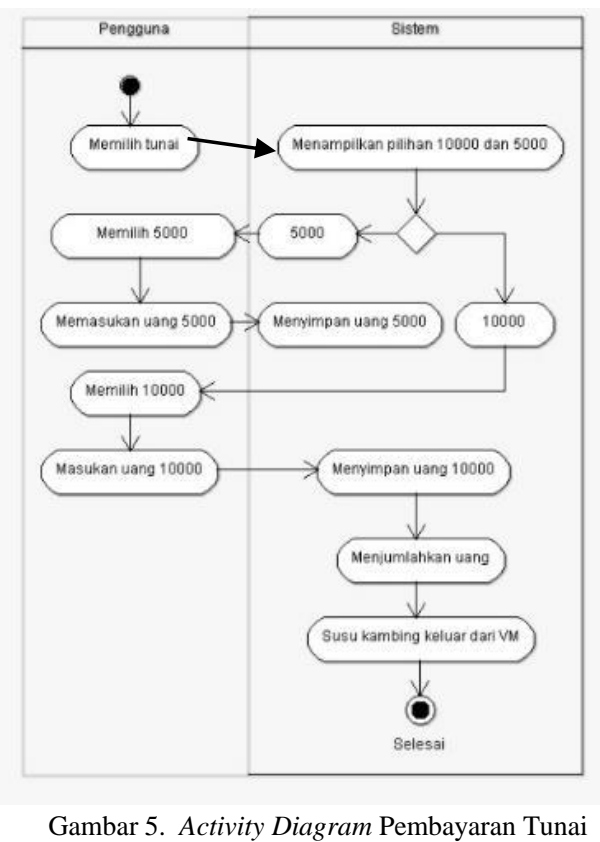

Pada gambar 5 menampilkan activity diagram proses pembayaran tunai. Saat pengguna memilih pembayaran tunai, sistem VM akan menampilkan pilihan untuk pembayaran menggunakan uang Rp.10.000 atau uang Rp.5.000. Jika Pengguna memilih memasukkan uang Rp.10.000, makan pengguna harus memasukkan uang Rp.10.000 dan sistem akan menyimpan uang Rp.10.000 tersebut. Selanjutnya, jika jumlah yang dimasukkan belum sesuai dengan jumlah yang harus dibayarkan, maka pengguna harus memilih memasukkan uang lagi. Jika Pengguna memilih memasukkan uang Rp.5.000, maka pengguna harus memasukkan uang Rp.5.000 dan sistem akan menyimpan uang Rp.5.000 tersebut. Selanjutnya, sistem akan menjumlahkan dua masukkan uang tersebut dan susu kambing akan keluar dari VM. 


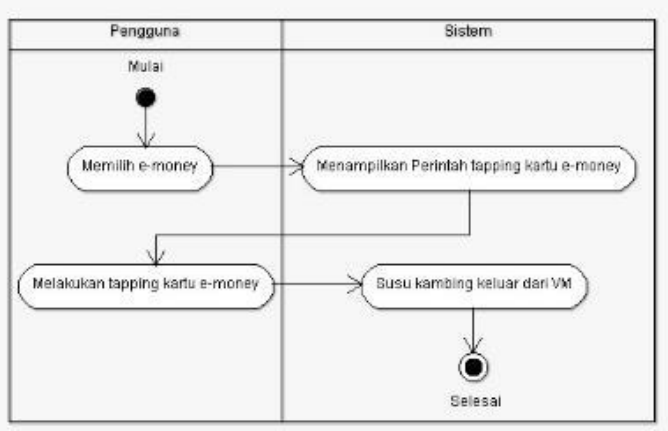

Gambar 6. Activity Diagram Pembayaran E-money

Pada gambar 6 menampilkan activity diagram proses pembayaran menggunakan e-money. Saat pengguna memilih melakukan pembayaran menggunakan $e$ money, maka sistem akan menampilkan perintah untuk melakukan tapping kartu e-money. Setelah pengguna melakukan tapping kartu e-money dan saldo dinyatakan cukup, maka susu kambing akan keluar dari VM.

3. Desain VM Susu Kambing Etawa

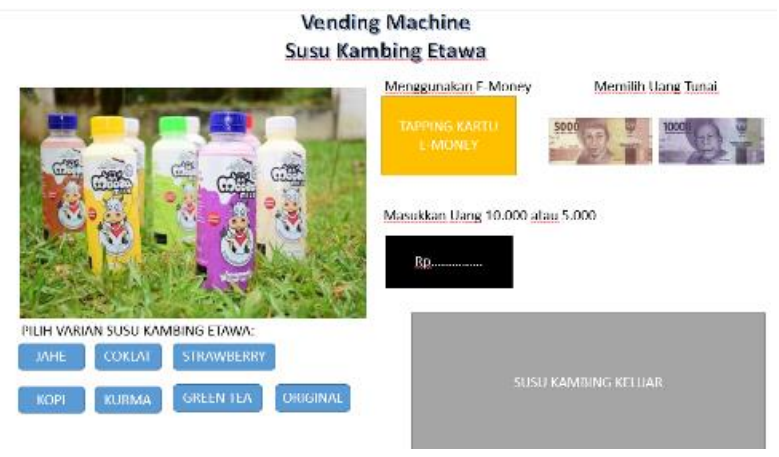

Gambar 7. Desain VM Susu Kambing Etawa

Pada gambar 7 merupakan tampilan antarmuka desain VM susu kambing etawa. Prinsip kerja VM susu kambing etawa ini, pengguna memilih varian susu kambing yang diinginkan. Setelah memilih, varian yang pilih akan menyala. Setelah itu, pengguna memilih metode pembayaran. Jika memilih menggunakan $e$ money, maka tempat tapping kartu e-money akan menyala dan pengguna dapat melakukan tapping kartu kemudian susu kambing akan keluar dari VM. Jika pengguna memilih menggunakan uang tunai, makan gambar uang 5.000 dan 10.000 akan menyala bergantian, setelah sudah salah satu dipilih maka hanya salah satu saja yang menyala. Jika uang yang dimasukkan masih belum cukup, maka gambar uang 5.000 dan 10.000 akan kembali menyala bergantian. Setelah uang sesuai dengan jumlah yang harus dibayar, maka susu kambing akan keluar dari VM.

\section{KESIMPULAN}

Berdasarkan perancangan finite state automata, dapat disimpulkan bahwa penggunaan nondeterministic finite state automata pada desain mesin penjualan susu kambing etawa otomatis dapat bermanfaat untuk penyebaran produk susu kambing etawa khususnya di kota-kota besar. VM susu kambing etawa menggunakan NFA menggunakan dua metode pembayaran yaitu tunai dan e-money dapat memudahkan pembeli dalam melakukan membayaran sesuai keinginan pembeli. Saran untuk penelitian selanjutnya adalah perlu adanya pengembangan VM dengan penambahan fitur isi saldo e-money dan penambahan jenis uang tunai yang bisa dimasukkan dalam mesin VM.

\section{REFERENSI}

[1] H. Wasiati and E. Faizal, "Peternakan Kambing Peranakan Etawa Di Kabupaten Bantul," J. Pengabdi. Masy. Univ. Merdeka Malang, vol. 3, no. 1, 2018.

[2] T. Suryani and F. Niswah, "Pemanfaatan Susu Kambing Etawa Dan Kedelai Sebagai Bahan Dasar Dangke ( Keju Khas Indonesia) Dengan Koagulan Ekstrak Jeruk Nipis,' Bioeksperimen J. Penelit. Biol., vol. 1, no. 2, pp. 45-52, 2015.

[3] R. W. Arief, N. Santri, and R. Asnawi, "Pengolahan Susu Kambing Ratna Wylis Arief et al Ratna Wylis Arief et al Pengolahan Susu Kambing," Teknol. Ind. Has. Pertan., vol. 23, no. 1, pp. 45-56, 2018.

[4] S. S. Adila, H. Arief, and M. Paturochman, "Kambing Perah Produk Peternakan Bangun Karso Farm Kecamatan Cijeruk Kabupaten Bogor Consumer Loyality and Preference Analysis To Dairy Goat Milk of Bangun Karso Farm , Cijeruk Subdistrict, Bogor District," pp. 1-11, 2017.

[5] R. Dewi, "ANALISIS KANDUNGAN ZAT GIZI DAN TOTAL UJI CEMARAN SUSU KAMBING PERANAKAN ETAWAH YANG DIKONSUMSI OLEH IBU HAMIL DAN ANAK - ANAK," Jur. Farm. Poltekkes kemenkes Makassar, vol. 14, no. 1, pp. 134-139, 2018.

[6] T. H. Wicaksono, F. D. Amrizal, and H. A. Mumtahana, "Pemodelan Vending Machine dengan Metode FSA ( Finite State Automata )," DoubleClick J. Comput. Inf. Technol., vol. 2, no. 2, pp. 66-69, 2019.

[7] A. S. Maulana, H. N. Azizah, and K. C. Kirana, "Implementasi Finite State Automata (FSA) dengan Simulasi Vending Machine pada Aplikasi Android," $J$. Edukasi Elektro, vol. 3, no. 2, pp. 110-120, 2020.

[8] A. M. Nisa and H. Kurniansyah, "Perancangan dan Implementasi Finite State Automata pada Pusheen Cat Maze Game dengan Adobe Flash," Res. Comput. Inf. Syst. Technol. Manag., vol. 2, no. 01, p. 13, 2019.

[9] N. D. Wirasbawa, L. Benedict, B. G. Santoso, F. Farhan, and A. Kusnadi, "Penerapan Konsep Non-Deterministic Finite Automata Untuk Pembuatan Sereal Menggunakan Mesin Jual Otomatis Dengan Dua Sistem Pembayaran," Simp. Nas. Ilm., no. November, pp. 440-448, 2019.

[10] E. E. Ogheneovo, "A New Algorithm for Determining the Equivalence of Two Finite-State Automata," J. Adv. Math. Comput. Sci., 2018.

[11] T. I. Saputra, F. Fauziah, and A. Gunaryati, "Simulasi Vending Machine Dengan Mengimplementasikan Finite State Automata," JOINTECS (Journal Inf. Technol. Comput. Sci., vol. 3, no. 3, 2018.

[12] R. I. A. EFFENDY, "PENERAPAN ALGORITMA FINITE STATE AUTOMATA ( FSA ) PADA GAME PENGENALAN HURUF UNTUK PENDIDIKAN ANAK 
USIA DINI," vol. VI, no. 02, pp. 46-57, 2011.

[13] N. Kulmukhanova, A. Daribay, I. Temirtayev, and U. Bassembek, "ZhardEM Medicine Vending Machine," Proc. 2nd Int. Conf. Comput. Netw. Commun. CoCoNet 2018, pp. 108-113, 2018.

[14] A. Swetapadma and A. Yadav, "An innovative finite state automata based approach for fault direction estimation in transmission lines," Measurement, vol. 99, pp. 13-22, 2017.

[15] F. A. Suharsih Ririn, "Penerapan Konsep Finite State Automata ( FSA ) pada Aplikasi Simulasi Vending Machine Yoghurt Walagri," J. Pendidik. Multimed., vol. 1, no. 2, pp. 71-78, 2019.

[16] R. Prahardis, D. Syauqi, and S. R. Akbar, "Implementasi Sistem Monitoring Polusi Udara Berdasarkan Indeks Standar Pencemaran Udara Dengan Pemodelan Finite State Machine," J. Pengemb. Teknol. Inf. dan Ilmu Komput., vol. 2, no. 9, 2018.

[17] M. A. I. P. 2 Yessy Willy Leimena 1, "Penerapan Finite State Automata Pada Pergantian Desktop Background," Penerapan Finite Autom. Pada Pergantian Deskt. Backgr. Yessy, vol. 6, no. 1, p. 43, 2017.

[18] M. Jamilah and W. Nurmansyah, "Rancangan Dan Implementasi Aplikasi Alat Bantu Pembelajaran Visualisasi Finite State Automata (Versi Pembuktian Graph ke Tupel)," Semin. Nas. Teknol. dan Bisnis, pp. 204-215, 2018.

[19] R. E. Mauboy and D. Manongga, "Penerapan Finite State Automata Pada Proses Peminjaman Buku di Perpustakaan Universitas Kristen Satya Wacana Artikel Ilmiah," no. 672013158, 2017.
[20] M. Y. F. Zaelani and Lelah, "Implementasi Finite State Automata Pada Aplikasi Pembelajaran Aksara Sunda," Implementasi Finite State Autom. Pada Apl. Pembelajaran Aksara Sunda, vol. 6, 2018.

[21] W. G. Gabriel Vangeran Saragih, Anas Faisal, "Desain Vending Machine Rokok Dengan Mengimplementasikan Finite State Automata," vol. 12, no. 1, pp. 55-60, 2020.

[22] A. Ardiansyah, N. Hardi, and W. Gata, "Identifikasi dan Recovery File JPEG dengan Metode Signature-Based Carving dalam Model Automata," Komputika J. Sist. Komput., vol. 9, no. 1, pp. 75-83, 2020.

[23] A. Maezar, B. Aji, V. Riyanto, G. Wijaya, and B. Rudianto, "Rancang Bangun Sistem Informasi Penjualan Produk Percetakan Berbasis Web Dengan Pemodelan UML," vol. 8, no. 1, pp. 56-61, 2018.

[24] G. Wijaya and M. Sari, "Perancangan Sistem Informasi Pengajuan Kredit Berbasis Web Pada PT . BPR Kredit Mandiri Indonesia Cabang Bekasi," IJSE - Indones. J. Softw. Eng., vol. 3, no. 2, pp. 98-104, 2015.

[25] Sahrul, F. Karimah, A. Muhazabah, A. D. Prasetyo, A. Yunita, and N. L. Zahra, "Pengembangan Aplikasi Permainan 'Pilah Sampah' Menggunakan Pemodelan Finite State Machine," J. Teknol., vol. 1, no. 1, pp. 38-46, 2018. 